\title{
Analisis Sistem Kerja Shift Terhadap Tingkat Kelelahan Dan Pengukuran Beban Kerja Fisik Perawat RSUD Karanganyar
}

\author{
Helma Hayu Juniar'), Rahmaniyah Dwi Astuti' ${ }^{2}$, dan Irwan Iftadi ${ }^{3)}$ \\ ${ }^{1)}$ Laboratorium Perancangan Sistem Kerja dan Ergonomi, Program Studi Teknik Industri, Fakultas \\ Teknik, Universitas Sebelas Maret Jl. Ir. Sutami 36A, Surakarta 57126, Indonesia \\ 2) Laboratorium Perancangan Sistem Kerja dan Ergonomi, Program Studi Teknik Industri, Fakultas \\ Teknik, Universitas Sebelas Maret J1. Ir. Sutami 36A, Surakarta 57126, Indonesia \\ 3) Laboratorium Perancangan Sistem Kerja dan Ergonomi, Program Studi Teknik Industri, Fakultas \\ Teknik, Universitas Sebelas Maret Jl. Ir. Sutami 36A, Surakarta 57126, Indonesia
}

\begin{abstract}
Karanganyar District Hospital uses a system of shift work is divided into three, namely the morning shift, afternoon shift and night shift. This study analyzed the levels of general fatigue experienced by nurses on the morning shift, afternoon shift and night shift using methods Bourdon Wiersma and questionnaire Subjective Rating Self Test and measurement physical workload using physiological methods of work. Based on the results obtained that the afternoon shift is a shift that has a level of fatigue the most high based on 3 parameters measured is speed, accuracy and constancy with methods Bourdon Wiersma Test and the morning shift and afternoon shift as a shift that has the workload of most high based on the results of measurements of the pulse to determine the amount of energy consumption, oxygen consumption and\% CVL to the nurse and then questionnaire.
\end{abstract}

Keywords : Bourdon Wiersma Test, Subjective Self Rating Test, Fisiologi, Nurses, Workload

\section{PENDAhUluan}

Pekerjaan merupakan sesuatu yang dibutuhkan oleh manusia. Kebutuhan tersebut terus bertambah seiring perkembangan teknologi yang semakin meningkat. Seseorang bekerja dikarenakan terdapat sesuatu yang ingin dicapai dan berharap aktivitas yang dilakukan akan mengubah keadaan menjadi lebih baik dari sebelumnya (Susetyo dkk., 2012). Pekerjaan yang tidak mengutamakan kesehatan dan keselamatan kerja akan menyebabkan besarnya beban kerja yang ditanggung baik secara fisik maupun mental. Hal tersebut menyebabkan pekerja mengalami kelelahan dan akan mempengaruhi kinerja. Kelelahan kerja adalah gejala yang berhubungan dengan penurunan efisiensi kerja, keterampilan, kebosanan, serta peningkatan kecemasan. Kata "lelah" memiliki arti tersendiri bagi setiap individu dan bersifat subjektif (Putri, 2008). Menurut The Circadian Learning Centre di Amerika Serikat bahwa ketika ritme sirkadian menjadi tidak sinkron maka fungsi tubuh akan terganggu sehingga mudah mengalami gangguan tidur, kelelahan, penyakit jantung, tekanan darah tinggi, perubahan suhu tubuh perubahan hormon, gangguan psikologi dan gangguan gastrointestinal (Doe, 2011).

Rumah sakit merupakan sebuah instansi yang memberikan sarana pelayanan kesehatan selama 24 jam sehingga dalam pekerjaannnya diperlukan sistem shift. Salah satu sumber daya yang dibutuhkan rumah sakit dalam merawat pasien adalah perawat. Peran perawat sangat penting karena sebagai ujung tombak dirawat inap dan merupakan tenaga yang paling lama berinteraksi dengan pasien yaitu selama 24 jam (Anjaswarni, 2002). Persentase kejadian stres sekitar $74 \%$ di alami perawat, mereka mengeluh dan kesal terhadap lingkungan yang menuntut kekuatan fisik dan keterampilan, hal ini merupakan penyebab stres perawat. Jika suatu pekerjaan tidak diimbangi dengan waktu istirahat yang cukup maka akan mempengaruhi fisik dan metal perawat sehingga menimbulkan kelelahan kerja.

Rumah Sakit Umum Daerah Karanganyar menggunakan sistem kerja shift yang terbagi menjadi tiga yaitu shift pagi, shift sore, dan shift malam. Untuk shift pagi selama 8 jam dimulai dari jam 8.00-14.00, kemudian shift sore selama 8 jam dimulai jam 14.00-20.00 dan shift malam selama 12 jam mulai dari jam 20.00-08.00. Karena pekerjaan perawat di rumah sakit tidak 
menganut sistem kerja tersebut sehingga pekerjaan dianggap tidak efisien maka perlu diketahui bagaimana analisis sistem kerja shift terhadap tingkat kelelahan perawat dibangsal.

Beberapa aktivitas yang dilakukan oleh perawat di bangsal bedah RSUD Karanganyar adalah merawat pasien sebelum dan sesudah operasi, selalu mengecek kondisi pasien sebelum operasi seperti melakukan injeksi, mengganti infus, dan lain-lain sesuai dengan rujukan dokter, melakukan evaluasi pasien, merawat luka, serta melanjutkan program-program dari advis dokter. Perawat tidak hanya berhadapan dengan pasien tetapi juga dengan dokter, sesama perawat serta bagian-bagian lain dari rumah sakit serta keluarga pasien. Interaksi dengan orang lain tersebut dan beban kerja yang berat menjadi tekanan tersendiri bagi perawat dirumah sakit (Saribu, 2012).

Tujuan dilakukannya penelitian ini adalah melakukan analisis sistem kerja shift terhadap tingkat kelelahan kerja serta pengukuran besar beban kerja fisik pada perawat di bangsal bedah RSUD Karanganyar sehingga didapatkan usulan perbaikan yang mungkin dapat dijadikan pertimbangan untuk meningkatkan kinerja perawat serta metode sistem kerja shift yang lebih baik dari sebelumnya. Serta manfaat yang dapat diberikan dari hasil penelitian ini adalah dengan mengetahui besar tingkat kelelahan kerja pada perawat di bangsal bedah RSUD Karanganyar diharapkan dapat mengurangi beban kerja yang ditanggung sehingga kinerja perawat dapat meningkat dan pekerjaan yang dilakukan dapat dibagi berdasarkan shift kerja agar beban kerja terbagi secara merata dan tidak terlalu berat sehingga tidak menimbulkan kelelahan kerja yang berlebihan

Metode yang digunakan dalam penelitian ini adalah kuesioner Subjective Self Rating Test. Kelebihan metode ini dari metode lainnya yaitu dapat dianalisis langsung dari gejala-gejala yang dirasakan oleh seseorang. Dikarenakan hasil dari pengukuran subjektif kurang kuat maka dilakukan pengukuran secara objektif menggunakan Bourdon Wiersma Test. Metode ini merupakan tes kognitif yang dikembangkan pada tahun 1982. Tes ini dipakai untuk mengevaluasi konsentrasi, perhatian, kecepatan bekerja untuk tugas-tugas yang rutin dan monoton, ketelitian kerja, dan daya tahan dalam bekerja (Susetyo dkk, 2012). Kelebihan dari metode ini yaitu dapat digunakan untuk aktivitas atau pekerjaan yang bersifat mental. Dikarenakan tidak semua metode dapat digunakan untuk pekerjaan yang sifatanya mental maka digunakanlah metode tersebut untuk mengukur tingkat kelelahan pada perawat bangsal bedah RSUD Karanganyar.

Saat tubuh melakukan kerja fisik akan terjadi perubahan pada kecepatan denyut jantung dan konsumsi oksigen terutama saat seseorang mulai bekerja, maka denyut jantung dan tingkat konsumsi oksigen meningkat sampai memenuhi kebutuhan namun saat sesorang berhenti bekerja, kecepatan denyut jantung dan konsumsi oksigen akan menurun secara perlahan-lahan sampai kondisi normal (Astuti, 2007). Salah satu faktor yang mempengaruhi kecepatan denyut nadi selain dari posisi tubuh yang mempengaruhi kecepatan denyut nadi selain posisi tubuh yang berubah (Rumatela, \& Maitimu, 2012).

Kelelahan fisik perawat akan diukur dengan fisiologi kerja. Penilaian beban kerja fisik yang digunakan adalah dengan metode tidak langsung yaitu dengan menghitung denyut nadi selama bekerja. Kelebihan dari metode tidak langsung ini yaitu hanya memerlukan peralatan yang sederhana dibandingkan dengan metode lain. Pengukuran fisiologi yang dilakukan adalah konsumsi energi, konsumsi oksigen, energi expenditure dan cardiovascular load (\%CVL).

\section{METODOLOGI PENELITIAN}

Tahapan pada penelitian ini dimulai dengan tahap identifikasi masalah yang meliputi identifikasi kelelahan kerja berdasarkan studi literature. Hasil yang didapatkan dari studi literatur ini berupa penyebaran kuesioner Subjective Self Rating Test sebagai pengukuran secara subjektif dan metode Bourdon Wiersma Test yang digunakan untuk mengukur kelelahan kerja secara objektif serta metode fisiologi untuk mengukur beban kerja fisik. Tahap selanjutnya yaitu observasi berupa identifikasi stakeholder, aktivitas perawat dan alur penanganan pasien. Pada tahap ini observasi dilakukan dengan melakukan pengamatan langsung keadaan rumah sakit dan wawancara. Pengamatan dilakukan untuk mengetahui kondisi kerja perawat di bangsal bedah RSUD Kabupaten Karanganyar. Sedangkan wawancara dilakukan langsung dengan ketua bangsal dan perawat. Pada tahapan ini bertujuan untuk mengetahui persepsi mengenai pengaruh sistem kerja shift terhadap kelelahan kerja yang dialami perawat yang terdapat di rumah sakit khususnya 
pada bangsal bedah, tahap-tahap pelaksanaan proses perawatan pasien sebelum dan sesudah operasi, jumlah perawat pada bangsal bedah, pembagian shift kerja setiap harinya, keluhan yang dialami perawat saat bekerja, jumlah pasien, serta kesalahan yang mungkin dan pernah terjadi yang berakibat fatal pada pasien.

Setelah itu tahapan selanjutnya dilakukan pengukuran kelelahan kerja dan pengukuran beban kerja fisik menggunakan tiga metode yaitu kuesioner untuk pengukuran subjektif, Bourdon Wiersma Test untuk pengukuran objektif dan metode fisiologi kerja untuk mengukur beban kerja fisik. Setelah dilakukan pengukuran kemudian dilakaukan perbandingan tingkat kelelahan dengan metode kuesioner dan Bourdon Wiersma Test dan beban kerja fisik pada shift pagi, shift sore dan shift malam untuk mengetahui shift mana yang memiliki tingkat kelelahan dan beban kerja fisik yang paling tinggi sehingga perlu dilakukan perbaikan. Tahapan selanjutnya yaitu analisis dan intepretasi hasil serta usulan perbaikan untuk mengatasi kelelahan kerja perawat. Dan tahap akhir kesimpulan dan saran

\section{HASIL DAN PEMBAHASAN}

Penelitian dilakukan pada perawat di bangsal bedah RSUD Karanganyar. Responden pada penelitian ini berjumlah 4 yaitu 2 laki-laki dan 2 perempuan. Responden diminta untuk mengisi kuesioner Subjective Self Rating Test terlebih dahulu untuk shift pagi, shift sore dan shift malam. Kelelahan subjektif dinilai dengan 4 skala likert. Jawaban untuk kuesioner tersebut terbagi menjadi 4 kategori yaitu sangat sering (SS) bernilai 4, sering (S) bernilai 3, kadang-kadang (K) bernilai 2 dan tidak pernah (TP) bernilai 1 (Faiz, 2014).

Berdasakan hasil pengisian kuesioner didapat jumlah skor pengisian sebagai berikut :

Tabel 1.1 Rekapitulasi hasil kuesioner Subjective Self Rating Test

\begin{tabular}{|c|l|c|c|c|c|c|c|}
\hline \multirow{2}{*}{ No } & \multirow{2}{*}{ Responden } & \multicolumn{2}{|c|}{ Shift Pagi } & \multicolumn{2}{c|}{ Shift Sore } & \multicolumn{2}{c|}{ Shift Malam } \\
\cline { 3 - 8 } & & Sebelum & Sesudah & Sebelum & Sesudah & Sebelum & Sesudah \\
\hline 1 & Responden I & 49 & 68 & 37 & 67 & 44 & 67 \\
\hline 2 & Responden II & 44 & 69 & 43 & 54 & 53 & 59 \\
\hline 3 & Responden III & 35 & 62 & 38 & 49 & 49 & 68 \\
\hline 4 & Responden IV & 44 & 58 & 35 & 53 & 51 & 70 \\
\hline
\end{tabular}

Berdasarkan desain penilaian kelelahan subjektif dengan menggunakan skala likert ini, akan diperoleh skor individu terendah sebesar 30 dan skor individu tertinggi 120. Hasil tersebut akan diklasifikasikan tingkat kelelahannya berdasakan tabel klasifikasi dibawah ini:

Tabel 1.2 klasifikasi Tingkat Kelelahan Subjektif

\begin{tabular}{|c|c|c|l|}
\hline $\begin{array}{c}\text { Tingkat } \\
\text { Kelelahan }\end{array}$ & Total Skor & $\begin{array}{c}\text { Klasifikasi } \\
\text { Kelelahan }\end{array}$ & \multicolumn{1}{|c|}{ Tindakan Perbaikan } \\
\hline 1 & $30-52$ & Rendah & Belum diperlukan adanya tindakan perbaikan \\
\hline 2 & $53-75$ & Sedang & Mungkin diperlukan adanya tindakan perbaikan \\
\hline 3 & $76-98$ & Tinggi & Diperlukan adanya tindakan perbaikan \\
\hline 4 & $99-120$ & Sangat Tinggi & Diperlukan tindakan perbaikan sesegera mungkin \\
\hline
\end{tabular}

Hasil dari uji paired sample T-test menggunakan SPSS statistics 20 terhadap rata-rata skor kelelahan menggunakan metode kuesioner Subjective Self Rating Test untuk shift pagi didapat nilai $\mathrm{t}=-7.192$ dan nilai $\mathrm{p}=0.006(\mathrm{p}<0.05)$ yang berarti terdapat perbedaan tingkat kelelahan secara bermakna saat sebelum melakukan aktivitas dan saat sesudah melakukan aktivitas pekerjaan pada shift pagi. Sedangkan pada shift sore didapat nilai $\mathrm{t}=-3.905$ dan nilai $\mathrm{p}=0.030$ $(\mathrm{p}<0.05)$ berarti bahwa terdapat perbedaan tingkat kelelahan secara bermakna saat sebelum melakukan aktivitas dan saat sesudah melakukan aktivitas pekerjaan pada shift sore. Pada shift malam didapat nilai $\mathrm{t}=4.852$ dan nilai $\mathrm{p}=0.020(\mathrm{p}<0.05)$ berarti bahwa terdapat perbedaan tingkat kelelahan secara bermakna saat sebelum melakukan aktivitas dan saat sesudah melakukan aktivitas pekerjaan pada shift malam. Hasil dari ketiga shift tersebut menunjukkan shift yang memiliki tingkat signifikansi paling tinggi adalah shift pagi dikarenakan pada shift tersebut terdapat banyak aktivitas fisik yang dilakukan seperti mengantar dan menjemput pasien dari 
bangsal ke kamar operasi ataupun sebaliknya serta indikator gejala kelelahan umum yang terdapat kuesioner lebih banyak merujuk pada kelelahan akibat aktivitas fisik.

\section{- Bourdon Wiersma Test}

Hasil pengukuran kelelahan secara objektif didapatkan skor rata-rata untuk responden pertama pada shift pagi saat sebelum bekerja dan sesudah bekerja, shift sore sebelum dan sesudah bekerja dan shift malam saat sebelum dan sesudah bekerja menggunakan uji Bourdon Wiersma Test sebagai berikut :

Tabel 1.3 Rata-rata Waktu Pengerjaan Bourdon Wiersma Test

\begin{tabular}{|c|l|c|c|c|c|c|c|}
\hline \multirow{2}{*}{ No } & \multirow{2}{*}{ Responden } & \multicolumn{2}{|c|}{ Shift Pagi } & \multicolumn{2}{c|}{ Shift Sore } & \multicolumn{2}{c|}{ Shift Malam } \\
\cline { 3 - 8 } & & Sebelum & Sesudah & Sebelum & Sesudah & Sebelum & Sesudah \\
\hline 1 & Responden I & 11.77 & 9.04 & 12.92 & 11.40 & 12.32 & 10.19 \\
\hline 2 & Responden II & 9.78 & 9.26 & 9.11 & 6.71 & 9.07 & 8.2 \\
\hline 3 & Responden III & 10.2 & 9.10 & 9.15 & 7.98 & 9.94 & 8.18 \\
\hline 4 & Responden & 10.21 & 8.72 & 9.52 & 7.65 & 10.30 & 9.19 \\
& & & & & & & \\
\hline
\end{tabular}

Tingkat kecepatan rata-rata untuk shift pagi, sore dan malam pada 4 responden perawat dapat dilihat pada gambar $1.2-1.4$ seperti berikut :

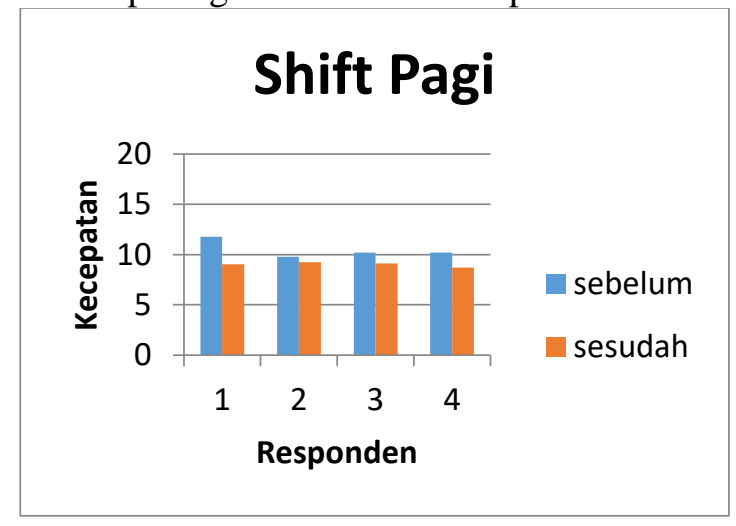

Gambar 1.2 Rata-rata tingkat kecepatan shift pagi

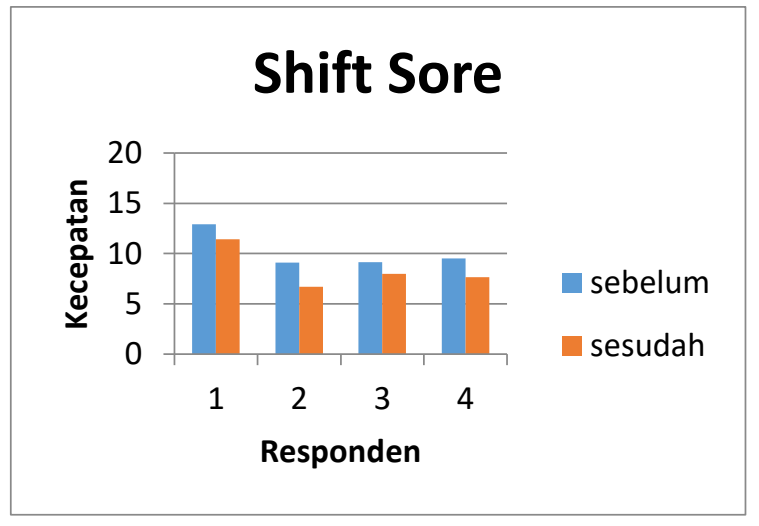

Gambar 1.3 Rata-rata tingkat kecepatan shift sore

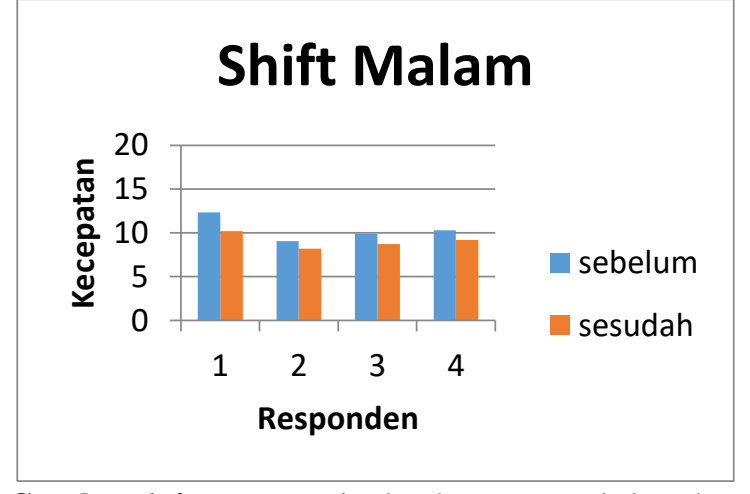

Gambar 1.4 Rata-rata tingkat kecepatan shift malam

Hasil dari uji paired sample T-test menggunakan SPSS statistics 20 terhadap rata-rata waktu kecepatan pengerjaan bourdon wiersma test pada shift pagi didapat nilai $\mathrm{t}=3.108$ dan nilai $\mathrm{p}=$ 0.053 ( $p>0.05$ ) yang berarti tidak terdapat perbedaan secara bermakna saat sebelum melakukan aktivitas dan saat sesudah melakukan aktivitas pekerjaan pada shift pagi. Sedangkan pada shift sore didapat nilai $\mathrm{t}=6.629$ dan nilai $\mathrm{p}=0.007(\mathrm{p}<0.05)$ berarti bahwa terdapat perbedaan secara bermakna saat sebelum melakukan aktivitas dan saat sesudah melakukan aktivitas pekerjaan pada shift sore. Pada shift malam didapat nilai $\mathrm{t}=4.852$ dan nilai $\mathrm{p}=0.017(\mathrm{p}<0.05)$ berarti bahwa terdapat perbedaan secara bermakna saat sebelum melakukan aktivitas dan saat sesudah melakukan aktivitas pekerjaan pada shift malam. Hasil dari ketiga shift tersebut menunjukkan shift yang memiliki tingkat signifikansi paling tinggi adalah shift sore dikarenakan pada shift tersebut perawat banyak melakukan interaksi dengan pasien maupun pihak keluarga yang 
bertanggung jawab atas pasien yang akan masuk bangsal. Jadi dapat disimpulkan bahwa shift sore memiliki tingkat pengaruh paling tinggi terhadap kelelahan perawat bangsal bedah RSUD Karanganyar.

\section{$>$ Tingkat Ketelitian}

Tingkat ketelitian dinilai berdasarkan kesalahan perawat dalam pengisian form Bourdon Wiersma Test. Kesalahan ini berupa kesalahan dalam mencoret dan berapa banyak kelompok 4 titik yang terlewati. Besarnya tingkat ketelitian akan dilihat pada tabel intepretasi sesuai dengan jumlah kesalahan responden dalam mencoret. Berikut hasil rekapitulasi tingkat ketelitian dari 4 responden :

Tabel 1.4 Rekapitulasi Hasil Tingkat Ketelitian Perawat Tiap Shift

\begin{tabular}{|c|c|c|c|c|c|c|c|}
\hline \multirow{2}{*}{ No } & \multirow{2}{*}{ Responden } & \multicolumn{2}{|c|}{ Shift Pagi } & \multicolumn{2}{c|}{ Shift Sore } & \multicolumn{2}{c|}{ Shift Malam } \\
\cline { 3 - 9 } & & Sebelum & Sesudah & Sebelum & Sesudah & Sebelum & Sesudah \\
\hline 1 & Responden I & 14 & 53 & 25 & 31 & 20 & 32 \\
\hline 2 & Responden II & 15 & 22 & 24 & 46 & 20 & 25 \\
\hline 3 & Responden III & 22 & 21 & 17 & 39 & 26 & 30 \\
\hline 4 & Responden IV & 19 & 31 & 21 & 36 & 18 & 33 \\
\hline
\end{tabular}

Tingkat ketelitian rata-rata untuk shift pagi, sore dan malam pada 4 responden perawat dapat dilihat pada gambar $1.5-1.7$ seperti berikut :

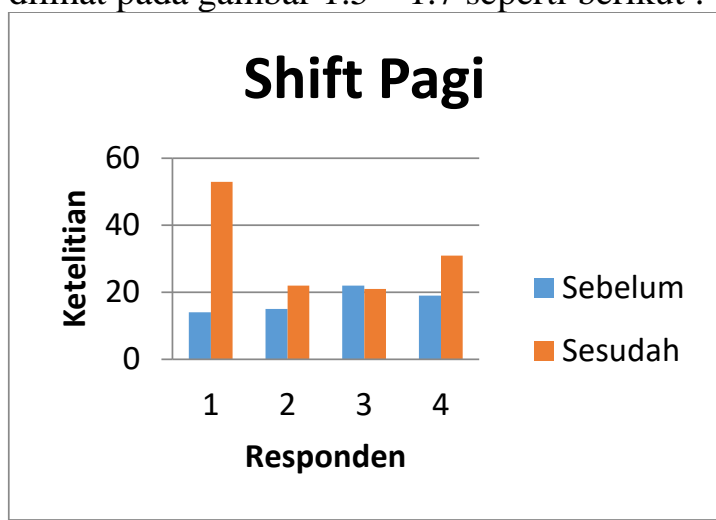

Gambar 1.5 Rata-rata tingkat ketelitian shift pagi

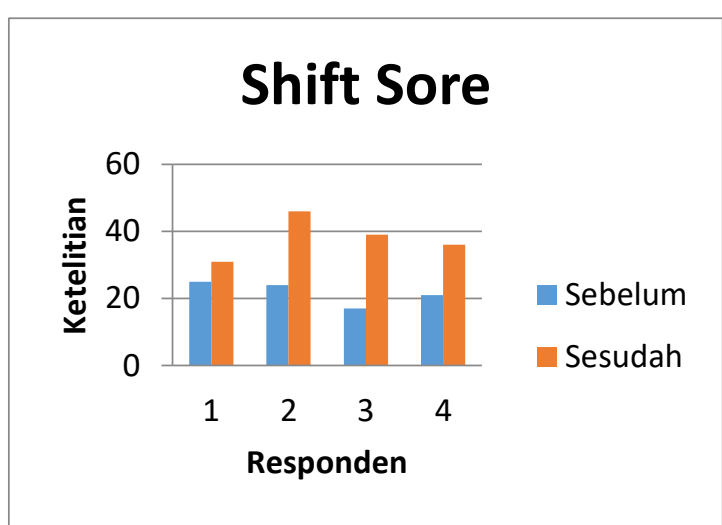

Gambar 1.6 Rata-rata tingkat ketelitian shift sore

\section{Shift Malam}

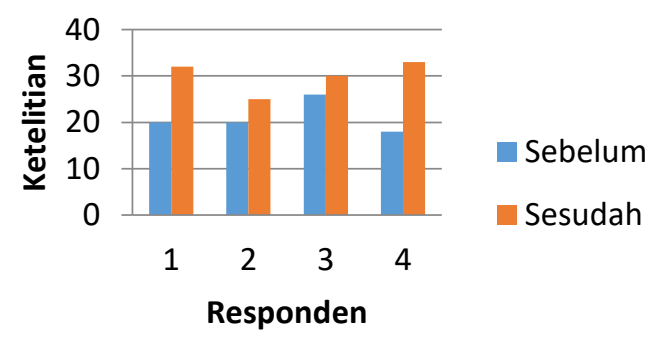

Gambar 1.7 Rata-rata tingkat ketelitian shift malam

Hasil dari uji paired sample T-test menggunakan SPSS statistics 20 terhadap tingakt ketelitian pengerjaan bourdon wiersma test pada shift pagi didapat nilai $\mathrm{t}=-1.643$ dan nilai $\mathrm{p}=0.199(\mathrm{p}>$ 0.05 ) yang berarti tidak terdapat perbedaan secara bermakna saat sebelum melakukan aktivitas dan saat sesudah melakukan aktivitas pekerjaan pada shift pagi. Sedangkan pada shift sore didapat nilai $\mathrm{t}=-4.283$ dan nilai $\mathrm{p}=0.023(\mathrm{p}<0.05)$ berarti bahwa terdapat perbedaan secara bermakna saat sebelum melakukan aktivitas dan saat sesudah melakukan aktivitas pekerjaan pada shift sore. Pada shift malam didapat nilai $\mathrm{t}=-3.362$ dan nilai $\mathrm{p}=0.044(\mathrm{p}<0.05)$ berarti bahwa terdapat perbedaan secara bermakna saat sebelum melakukan aktivitas dan saat sesudah melakukan aktivitas pekerjaan pada shift malam. Hasil dari ketiga shift tersebut menunjukkan shift yang memiliki tingkat signifikansi paling tinggi adalah shift sore. 


\section{Tingkat Kekonstanan}

Tingkat kekonstanan dihitung dengan membandingkan rasio antara jumlah kuadrat dari deviasi dan waktu rata-rata pengerjaan tiap baris kelompok titik-titik. Berikut adalah hasil rekapitulasi serta perhitungan tingkat konstansi pada 4 responden :

Tabel 1.5 Rekapitulasi Tingkat Konstansi Perawat

\begin{tabular}{|c|c|c|c|c|c|c|c|}
\hline \multirow{2}{*}{ No } & \multirow{2}{*}{ Responden } & \multicolumn{2}{|c|}{ Shift Pagi } & \multicolumn{2}{c|}{ Shift Sore } & \multicolumn{2}{c|}{ Shift Malam } \\
\cline { 3 - 8 } & & Sebelum & Sesudah & Sebelum & Sesudah & Sebelum & Sesudah \\
\hline 1 & Responden I & 3.12 & 8.05 & 19.62 & 8.22 & 20.45 & 6.87 \\
\hline 2 & Responden II & 6.42 & 8.04 & 6.47 & 4.54 & 5.86 & 8.82 \\
\hline 3 & Responden III & 14.56 & 7.09 & 10.76 & 8.13 & 8.29 & 6.52 \\
\hline 4 & Responden IV & 6.88 & 5.16 & 11.14 & 9.64 & 11.41 & 8.93 \\
\hline
\end{tabular}

Tingkat konstansi rata-rata untuk shift pagi, sore dan malam pada 4 responden perawat dapat dilihat pada gambar $1.8-1.10$ seperti berikut :

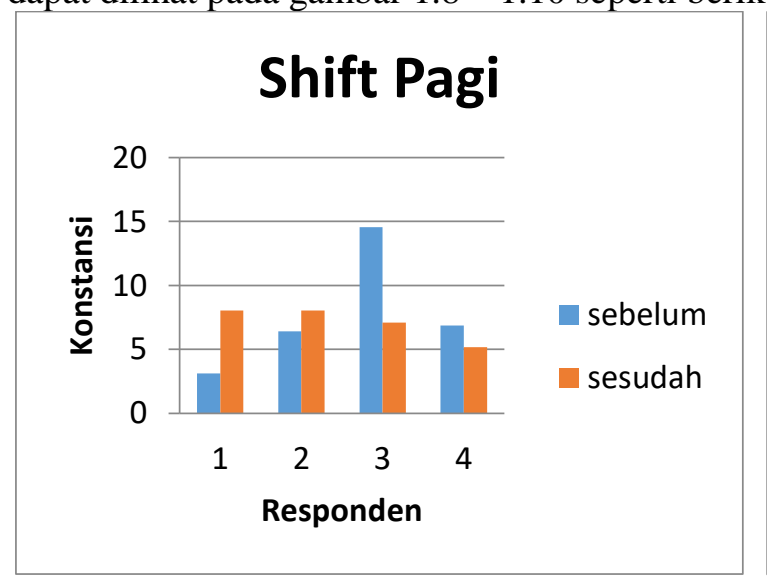

Gambar 1.8 Rata-rata tingkat konstansi shift pagi

\section{Shift Sore}

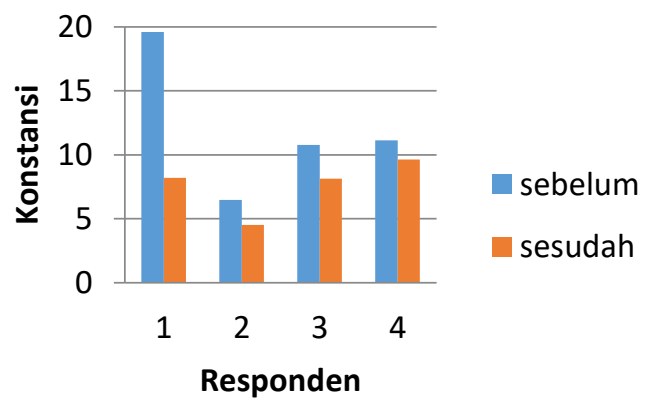

Gambar 1.9 Rata-rata tingkat konstansi shift sore

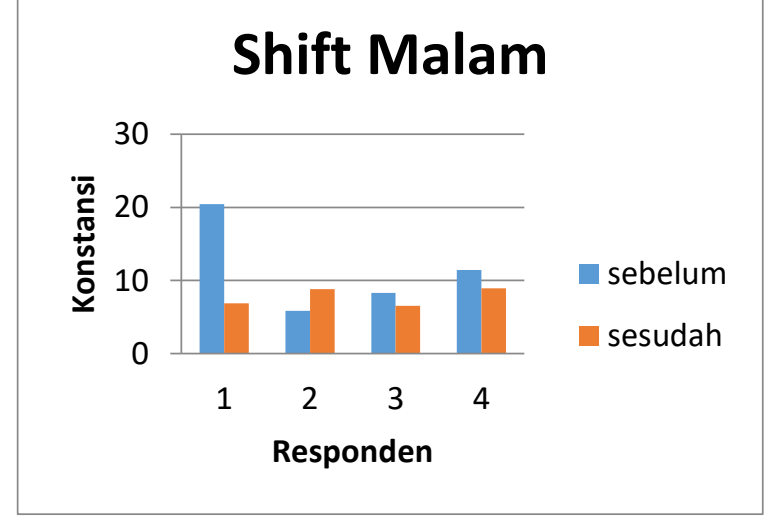

Gambar 1.10 Rata-rata tingkat konstansi shift malam

Hasil dari uji paired sample T-test menggunakan SPSS statistics 20 terhadap tingakt konstansi pengerjaan bourdon wiersma test pada shift pagi didapat nilai $\mathrm{t}=0.250$ dan nilai $\mathrm{p}=0.819(\mathrm{p}>$ 0.05 ) yang berarti tidak terdapat perbedaan secara bermakna saat sebelum melakukan aktivitas dan saat sesudah melakukan aktivitas pekerjaan pada shift pagi. Sedangkan pada shift sore didapat nilai $\mathrm{t}=2.278$ dan nilai $\mathrm{p}=0.107(\mathrm{p}>0.05)$ berarti tidak terdapat perbedaan secara bermakna saat sebelum melakukan aktivitas dan saat sesudah melakukan aktivitas pekerjaan pada shift sore. Pada shift malam didapat nilai $\mathrm{t}=0.669$ dan nilai $\mathrm{p}=0.552(\mathrm{p}>0.05)$ berarti bahwa tidak terdapat perbedaan secara bermakna saat sebelum melakukan aktivitas dan saat sesudah melakukan aktivitas pekerjaan pada shift malam. Hasil dari ketiga shift tersebut menunjukkan shift yang memiliki tingkat signifikansi paling tinggi adalah shift sore. 
- Pengukuran Beban Kerja menggunakan Metode Fisiologi Kerja

Pengukuran beban kerja fisik dilakukan dengan mengukur besar denyut jantung perawat saat sebelum dan sesudah melakukan pekerjaan dalam satu menit. Berikut hasil rekapitulasi denyut nadi responden 1 hingga responden 4 saat sebelum dan sesudah bekerja untuk shift pagi, shift sore dan shift malam.

Tabel 1.6 Rekapitulasi Pengukuran Denyut Nadi Perawat /mnt

\begin{tabular}{|l|l|c|c|c|c|c|c|}
\hline \multirow{2}{*}{ No } & \multirow{2}{*}{ Responden } & \multicolumn{2}{|c|}{ Shift Pagi } & \multicolumn{2}{c|}{ Shift Sore } & \multicolumn{2}{c|}{ Shift Malam } \\
\cline { 3 - 8 } & & Sebelum & Sesudah & Sebelum & Sesudah & Sebelum & Sesudah \\
\hline 1 & Responden I & 55 & 99 & 61 & 92 & 61 & 96 \\
\hline 2 & Responden II & 65 & 90 & 67 & 98 & 69 & 97 \\
\hline 3 & Responden III & 70 & 97 & 74 & 91 & 72 & 92 \\
\hline 4 & Responden IV & 67 & 89 & 69 & 93 & 66 & 90 \\
\hline
\end{tabular}

\section{Konsumsi Energi.}

Dalam penentuan konsumsi energi biasanya digunakan suatu bentuk hubungan energy dengan kecepatan denyut jantung yaitu sebuah persamaan regresi kuadratis sebagai berikut: $\mathrm{Y}=1,80411-0,0229038 \mathrm{X}+4,71733 \times 10^{-4} \mathrm{X}^{2}$ $\mathrm{KE}=\mathrm{Et}-\mathrm{Ej}$

Denyut nadi saat sebelum dan sesudah bekerja akan digunakan untuk mengukur besarnya konsumsi energi pada 4 responden perawat di bangsal bedah RSUD Karanganyar. Perhitungan konsumsi energi dilakukan untuk mengetahui kategori beban kerja fisik. Sebelum mengetahui besarnya konsumsi energy perlu dilakukan perhitungan energy expenditure saat sebelum dan sesudah melakukan pekerjaan Berikut hasil perhitungan energy expenditure dan konsumsi energy responden 1 sampai 4 beserta rumus perhitungan:

Tabel 1.7 Rekapitulasi Konsumsi Energi Perawat

\begin{tabular}{|c|c|c|c|c|c|}
\hline \multicolumn{7}{|c|}{ Konsumsi Energi } \\
\hline \multirow{4}{*}{$\begin{array}{c}\text { Responden } \\
1\end{array}$} & Shift & Et & Ej & KE & Klasifikasi \\
\cline { 2 - 6 } & Pagi & 4.160089 & 1.971393325 & 2.188696 & Very Light \\
\cline { 2 - 6 } & Sore & 3.689709 & 2.162296693 & 1.527412 & Very Light \\
\cline { 2 - 6 } & Malam & 3.952837 & 2.162296693 & 1.79054 & Very Light \\
\hline \multirow{3}{*}{$\begin{array}{c}\text { Responden } \\
2\end{array}$} & Pagi & 3.5638053 & 2.308434925 & 1.255370375 & Very Light \\
\cline { 2 - 6 } & Sore & 4.090061332 & 2.387164837 & 1.702896495 & Very Light \\
\cline { 2 - 6 } & Malam & 4.020977197 & 2.469668613 & 1.551308584 & Very Light \\
\hline \multirow{3}{*}{$\begin{array}{c}\text { Responden } \\
3\end{array}$} & Pagi & 4.020977197 & 2.5123357 & 1.508641497 & Very Light \\
\cline { 2 - 6 } & Sore & 3.626285173 & 2.692438708 & 0.933846465 & Very Light \\
\cline { 2 - 6 } & Malam & 3.689708512 & 2.600500272 & 1.08920824 & Very Light \\
\hline \multirow{2}{*}{$\begin{array}{c}\text { Responden } \\
4\end{array}$} & Pagi & 3.502268893 & 2.387164837 & 1.115104056 & Very Light \\
\cline { 2 - 6 } & Sore & 3.754075317 & 2.469668613 & 1.284406704 & Very Light \\
\cline { 2 - 6 } & Malam & 3.626285173 & 2.347328148 & 1.216477 & Very Light \\
\hline
\end{tabular}

\section{Konsumsi Oksigen}

Untuk menentukan seberapa besar konsumsi oksigen yang diperlukan digunakan metode konvensional Tayyari untuk mengestimasi $\mathrm{VO}_{2}$ didasarkan pada berat badan dan denyut jantung selama bekerja. Tayyari merumuskan sebuah persamaan untuk menghitung konsumsi oksigen maksimal, yaitu:

$\mathrm{VO} 2 \mathrm{max}=\frac{0.263(\mathrm{~Wb}+10) \mathrm{V}+13.15}{\mathrm{HR}+\mathrm{G}-72} \times \mathrm{AG}$

Untuk mengetahui besarnya energy kerja fisik salah satu cara nya adalah dengan membandingkan konsumsi oxygen dengan laju detak nadi/jantung. Oksigen yang dikonsumsi oleh seseorang dipengaruhi oleh intensitas pekerjaan yang dilakukan. Konsumsi oksigen dinyatakan dengan $\mathrm{VO}_{2}$ Max. Berikut hasil rekapitulasi dan perhitungan konsumsi oksigen responden 1 hingga 4 perawat bangsal bedah RSUD Karanganyar: 
Tabel 1.8 Rekapitulasi Perhitungan Konsumsi Oksigen Perawat

\begin{tabular}{|c|c|c|c|c|c|c|c|c|}
\hline \multicolumn{8}{|c|}{ Perhitungan Konsumsi Oksigen (Aktivitas) } \\
\hline \multirow{4}{*}{$\begin{array}{c}\text { Responden } \\
1\end{array}$} & Shift & Wb & V & $\begin{array}{c}\text { HR } \\
\text { aktivitas }\end{array}$ & G & AG & $\begin{array}{c}\text { VO2max } \\
\text { aktivitas }\end{array}$ & Klasifikasi \\
\cline { 2 - 9 } & Pagi & 70 & 1 & 99 & 1 & 0.9156 & 1.118013 & Moderate \\
\cline { 2 - 9 } & Sore & 70 & 1 & 92 & 1 & 0.9156 & 1.490684 & Moderate \\
\cline { 2 - 9 } & Malam & 70 & 1 & 96 & 1 & 0.9156 & 1.25217456 & Moderate \\
\hline \multirow{3}{*}{$\begin{array}{c}\text { Responden } \\
2\end{array}$} & Pagi & 58 & 1 & 90 & 1 & 0.901 & 1.471664947 & Moderate \\
\cline { 2 - 9 } & Sore & 58 & 1 & 98 & 1 & 0.901 & 1.035616074 & Moderate \\
\cline { 2 - 9 } & Malam & 58 & 1 & 97 & 1 & 0.901 & 1.075447462 & Moderate \\
\hline \multirow{3}{*}{$\begin{array}{c}\text { Responden } \\
3\end{array}$} & Pagi & 69 & 1 & 97 & 0 & 0.8645 & 1.17319566 & Moderate \\
\cline { 2 - 9 } & Sore & 69 & 1 & 91 & 0 & 0.8645 & 1.5436785 & Moderate \\
\cline { 2 - 9 } & Malam & 69 & 1 & 92 & 0 & 0.8645 & 1.4664946 & Moderate \\
\hline \multirow{2}{*}{$\begin{array}{c}\text { Responden } \\
4\end{array}$} & Pagi & 74 & 1 & 89 & 0 & 0.9375 & 1.9435 & Moderate \\
\cline { 2 - 8 } & Sore & 74 & 1 & 93 & 0 & 0.9375 & 1.5733 & Moderate \\
\cline { 2 - 8 } & Malam & 74 & 1 & 91 & 0 & 0.9375 & 1.8355 & Moderate \\
\hline
\end{tabular}

\section{\% CVL (Cardiovascular Load)}

klasifikasi beban kerja berdasarkan peningkatan denyut nadi kerja yang dibandingkan dengan denyut nadi maksimum karena beban kardiovaskular (cardiovascular load $=\% C V L$ ) yang dihitung dengan rumus sebagai berikut:

$$
\% C V L=\frac{\text { Denyutnadikerja }- \text { Denyutnadiistirahat }}{\text { Denyutnadimaksimum }- \text { Denyutistirahat }} \times 100 \%
$$

Laki-laki $\quad \Rightarrow$ Denyut Nadi Maksimum $=220-$ umur

Perempuan $\Rightarrow$ Denyut Nadi Maksimum $=200-$ umur (Tarwaka, 2004)

Perhitungan cardiovascular load digunakan sebagai estimasi untuk menentukan klasifikasi beban kerja bedasarkan peningkatan denyut nadi kerja yang dibandingkan dengan denyut nadi maksimum. Berikut rekapitulasi hasil perhitungan cardiovascular load terhadap 4 responden :

Tabel 1.9 Rekapitulasi Perhitungan \% CVL Perawat

\begin{tabular}{|c|c|c|c|c|c|c|}
\hline \multicolumn{9}{|c|}{ Perhitungan \% CVL } \\
\hline \multirow{4}{*}{$\begin{array}{c}\text { Responden } \\
1\end{array}$} & Shift & $\begin{array}{c}\text { DN } \\
\text { Kerja }\end{array}$ & $\begin{array}{c}\text { DN } \\
\text { Istirahat }\end{array}$ & $\begin{array}{c}\text { DN } \\
\text { Max }\end{array}$ & \%CVL & Klasifikasi \\
\cline { 2 - 7 } & Pagi & 99 & 55 & 192 & $32.12 \%$ & Diperlukan perbaikan \\
\cline { 2 - 7 } & Sore & 92 & 61 & 192 & $23.66 \%$ & Tidak terjadi kelelahan \\
\cline { 2 - 7 } & Malam & 96 & 61 & 192 & $26.72 \%$ & Tidak terjadi kelelahan \\
\hline \multirow{3}{*}{$\begin{array}{c}\text { Responden } \\
2\end{array}$} & Pagi & 90 & 65 & 190 & $20 \%$ & Tidak terjadi kelelahan \\
\cline { 2 - 7 } & Sore & 98 & 67 & 190 & $25.20 \%$ & Tidak terjadi kelelahan \\
\cline { 2 - 7 } & Malam & 97 & 69 & 190 & $23.14 \%$ & Tidak terjadi kelelahan \\
\hline \multirow{4}{*}{$\begin{array}{c}\text { Responden } \\
3\end{array}$} & Pagi & 97 & 70 & 185 & $23.48 \%$ & Tidak terjadi kelelahan \\
\cline { 2 - 7 } & Sore & 91 & 74 & 185 & $15.32 \%$ & Tidak terjadi kelelahan \\
\cline { 2 - 7 } & Malam & 92 & 72 & 185 & $17.70 \%$ & Tidak terjadi kelelahan \\
\hline \multirow{3}{*}{$\begin{array}{c}\text { Responden } \\
4\end{array}$} & Pagi & 89 & 67 & 195 & $17.19 \%$ & Tidak terjadi kelelahan \\
\cline { 2 - 7 } & Sore & 91 & 66 & 195 & $19.05 \%$ & Tidak terjadi kelelahan \\
\cline { 2 - 7 } & Malam & 93 & 69 & 195 & $18.60 \%$ & Tidak terjadi kelelahan \\
\hline
\end{tabular}

Berdasarkan perhitungan konsumsi energy, responden 1 dan 3 memiliki beban kerja fisik paling tinggi di shift pagi sedangkan responden 2 dan 4 memiliki beban kerja fisik paling tinggi di shift sore. Sedangkan untuk pengukuran konsumsi oksigen, responden 1 dan 3 memiliki beban kerja fisik paling tinggi pada shift sore dan untuk responden 2 dan 4 memiliki beban kerja fisik 
paling tinggi di shift pagi. Serta berdasarkan pengukuran presentase CVL responden 1 dan 3 memiliki presentase CVL tertinggi di shift pagi dan untuk responden 2 dan 4 di shift sore.

Hal tersebut dikarenakan pada shift pagi dan sore terdapat banyak aktivitas fisik yang dilakukan seperti mengantar dan menjemput pasien dari bangsal ke kamar operasi ataupun sebaliknya serta terdapat aktivitas mental yang dapat mempengaruhi tingginya kenaikan denyut nadi saat bekerja.

Perbandingan antar tiga metode dapat disimpulkan bahwa shift sore merupakan shift yang memiliki tingkat kelelahan paling tinggi berdasarkan 3 parameter yang diukur yaitu kecepatan, ketelitian, dan konstansi dengan metode Bourdon Wiersma Test serta shift pagi sebagai shift yang memiliki tingkat kelelahan paling tinggi berdasarkan hasil kuesioner Subjective Self Rating Test . Untuk responden 1 dan 3 memiliki tingkat beban kerja fisik paling tinggi di shift pagi berdasarkan pengukuran konsumsi energy dan presentase CVL sedangkan untuk responden 2 dan 4 memiliki tingkat beban kerja fisik paling tinggi di shift sore berdasarkan perhitungan konsumsi oksigen. Faktor lain penyebab tingginya tingkat kelelahan pada shift sore berdasarkan metode Bourdon Wiersma Test yaitu terdapat aktivitas yang sudah dilakukan sebelumnya diluar pekerjaan sebagai perawat seperti melakukan pekerjaan rumah terlebih dahulu. Sedangkan shift pagi banyak aktivitas yang sifatnya fisik sehingga menyebabkan tingginya denyut nadi saat setelah bekerja.

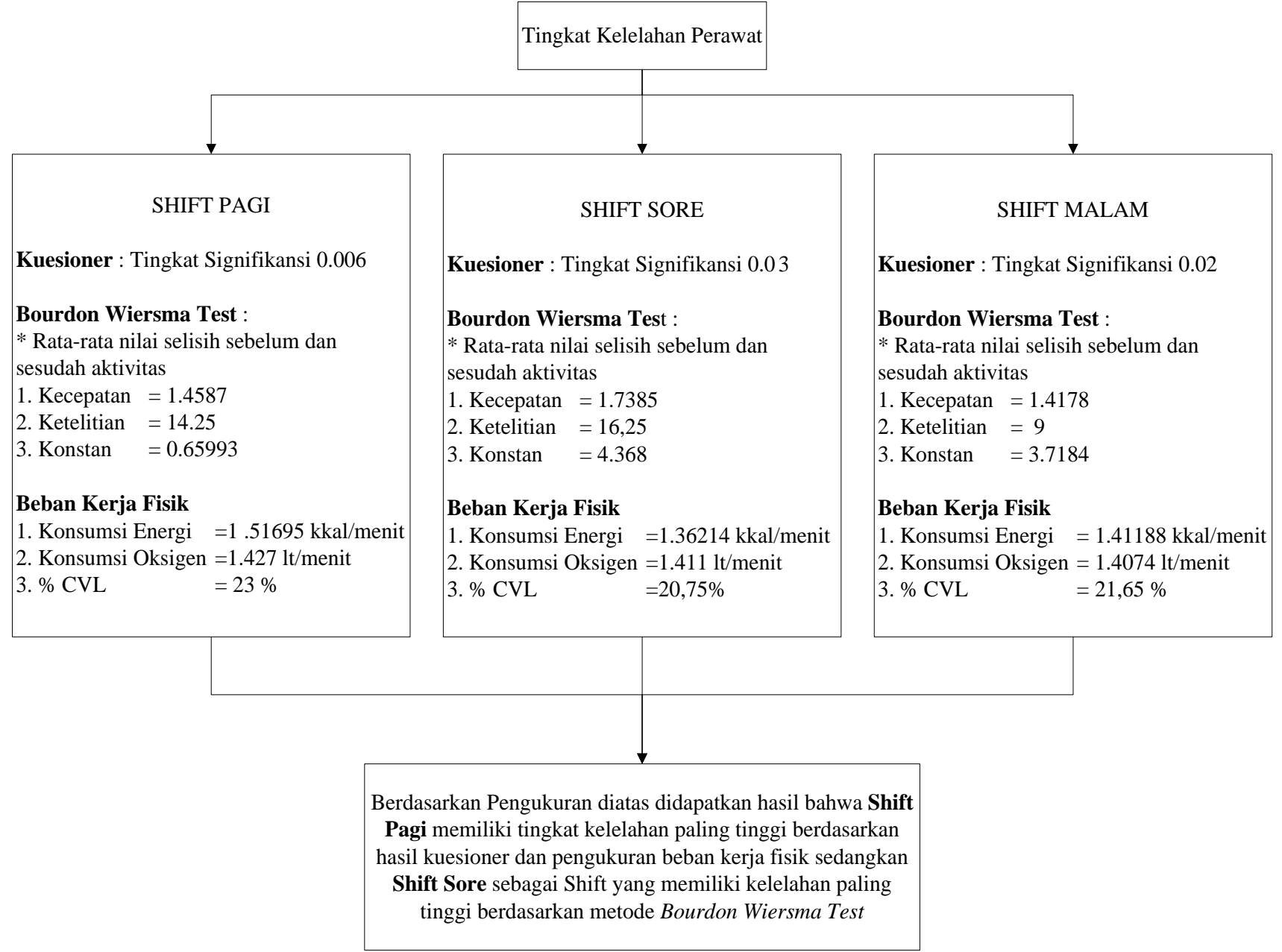

Gambar 1.11 Perbandingan Tingkat Kelelahan Kerja dan Beban Kerja Fisik 


\section{SIMPULAN}

Berdasarkan hasil pengukuran subjektif menggunakan kuesioner Subjective Self Rating Test didapatkan hasil bahwa ketiga shift tersebut berada dalam klasifikasi rendah dan sedang dengan tindakan mungkin perlu dilakukan adanya perbaikan dan shift yang memiliki tingkat kelelahan paling tinggi berdasarkan hasil kuesioner adalah shift pagi. Sedangkan hasil pengukuran menggunakan metode Bourdon Wiersma didapatkan hasil untuk tingkat kecepatan, tingkat ketelitian dan tingkat konstansi dapat disimpulkan bahwa tingkat kelelahan paling tinggi ada pada shift sore. Dan berdasarkan hasil perhitungan konsumsi energy dengan menggunakan metode fisiologi kerja terhadap 4 responden bangsal bedah didapatkan hasil responden 1 dan 3 memiliki beban kerja fisik paling tinggi di shift pagi sedangkan responden 2 dan 4 memiliki beban kerja fisik paling tinggi di shift sore. Sedangkan untuk konsumsi oksigen, responden 1 dan 3 memiliki beban kerja fisik paling tinggi pada shift sore dan untuk responden 2 dan 4 memiliki beban kerja fisik paling tinggi di shift pagi. Serta berdasarkan pengukuran presentase CVL didapatkan responden 1 dan 3 memiliki presentase CVL tertinggi di shift pagi dan untuk responden 2 dan 4 di shift sore.

Terdapat beberapa usulan perbaikan yang dapat dijadikan pertimbangan pihak rumah sakit untuk menurunkan tingkat kelelahan perawat yaitu dengan menambah tenaga kerja perawat, membagi pekerjaan berdasarkan umur perawat, pihak rumah sakit dapat memerikan fasilitas pelatihan ataupun sosialisasi kepada perawat dan staff rumah sakit, pergantian sistem pendokumentasian manual menjadi komputerisasi untuk mempermudah pekerjaan, memberikan aturan mengenai jam masuk kerja perawat bangsal bedah untuk meminimalisir terjadinya miss komunikasi dengan perawat dishift sebelumnya jika terlambat, untuk perawat yang mengalami sistem kerja shift sebaiknya menghindari pekerjaan sampingan diluar pekerjaannya sebagai perawat.

\section{DAFTAR PUSTAKA}

Anjaswarni, Tri, Budi Anna Keliat, \& Luknis Sabri. (2002). Analisis Tingkat Kepuasan Klien terhadap Perilaku Caring Perawat di Rumah Sakit Umum Daerah Dr Syaiful Anwar Malang. Jurnal keperawatan Indonesia. Volume 6. nomor 2. 41 - 49.

Astuti, D.R. 2007. Analisa Pengaruh Aktivitas Kerja dan Beban Angkat Terhadap Kelelahan Muskuloskeletal. Vol 10, No.2. 27-32

Doe, N., 2012. Gangguan Tidur pada Perawat Pekerja Shift. Skripsi Program Studi Keperawatan Fakultas Ilmu Kesehatan Universitas Kristen Satya Wacana. Salatiga

Faiz, N., 2014. Faktor-faktor yang Berhubungan dengan Kelelahan Kerja pada Pekerja Operator SPBU di Kecamatan Ciputat Tahun 2014. Skripsi Fakultas Kedokteran dan Ilmu Kesehatan Universitas Islam Negeri Syaruf Hidayatullah: Jakarta.

Putri,. D. P. 2008. Hubungan Faktor Internal dan Eksternal Pekerja Terhadap Kelelahan (Fatigue) Pada Operator Alat Besar PT. Indonesia Power Unit Bisnis Pembangkitan Suralaya Periode Tahun 2008. Skripsi Fakultas Kesehatan Masyarakat Universitas Indonesia: Depok.

Rumatela, A., Maitimu, E.N. 2012. Analisis Keluhan Psikis dan Fisik Karyawan dengan Menggunakan Metode Pshychophysiologi. Jurnal Teknologi. Vol 9, No.2. Hal 1048-1055.

Saribu, S.D. 2012. Hubungan Beban Kerja dengan Stres Kerja Perawat Pelaksana di Ruang IGD dan ICU RSUD Haji Abdul Manan Simatupang

Kisaran. Skripsi Sarjana keperawatan, Jurusan Sarjana Keperawatan, Fakultas Keperawatan, Universitas Sumatera Utara, Sumatera.

Susetyo, S., Oesman, I.T., Sudharman, T.S. 2012. Pengaruh Shift Kerja Terhdap Kelelahan Karyawan dengan Metode Bourdon Wiersma dan 30 Items of Rating Scale. Jurnal Teknologi. Vol 5, No.1. Hal 32-39

Widodo, S. 2008. Penentuan Lama Waktu Istirahat Berdasarkan Beban Kerja dengan Menggunakan Pendekatan Fisiologis. Skripsi Fakultas Teknik. Universitas Muhammadiyah Surakarta. 